\title{
DAMAGE IN THE WESTPORT AREA
}

*T. M. Chandler \& J. R. Bennett

\section{Background}

1. (a) The area concerned in this report is the coastal strip from the Buller River northwards to Maramea. The main town in the area is Westport which is a Borough with 1300 dwelling houses. Many of the buildings go back to the early 1900 's and fewer new houses and commercial buildings have been built in latter years than in most New Zealand towns of a similar age。

(b) Within the last 40 years Westport has suffered three earthquakes which have caused considerable damage to buildings - Buller 1929 Westport 1962 - Inangahua 1968. The latter two earthquakes occurred after the introduction of the Earthquake \& War Damage Act. From the 1962 earthquake more than 1500 claims were recelved from the district while in 1968 more than 2200 claims were registered. Probably within the Borough of liestport the number of claims from both the shocks was about the same. However in the 1968 shock there were many more claims from the townships further north of Westport - Waimangaroa, Granity, Hector, Nikau, Denniston, Seddonville and Karamea.

\section{Type of damage experienced}

2. As in the 1962 earthquake the types of damage were:-

(a) Chimneys: As in most earthquakes in New Zealand the outstanding damage was to chimneys. In the area most chimneys are of unreinforced brick. These failed mainly at the flashing line, but a smaller proportion failed at the gather or at the base itself. Concrete block chimneys failed either at the gather or between the chimney and the concrete foundation. This is due to the lack of reinforcing at these points. There was one outstanding example of the failure of a reinforced concrete external chimney. It fell outwards from the building and lay on the ground completely intact.

(b) Roof damage from fallen chimneys.

(c) Cracking of unit masonry walls.

$i$ Both brick and concrete block bearing walls especially the older structures were severely damaged. In many cases the damage consisted of the opening up or extension of old cracking.

iI Brick and concrete block veneer buildings cracked.

(d) Racking of interior linings with the splitting of wall papers at the junction of wall boards or in corners.

(e) Toilet Pans: These fractured either at or close to the junction with the soil pipe. There are flexible joints avallable in New Zealand and their use would reduce the incidence of damage in this common failure.

(f) Fallen stock: A fair proportion of claims concerned fallen stock mainly from grocery or departmental stores.

+ Insurance Assessor, Chandler \& Taylor Limited 


\section{Disturbance of foundations}

3. There was some disruption of the ground in Westport itself apparently due to the nature of the ground. Foundations were affected badly in the various areas, but this was particularly noticeable in the region around Shellswell street. This area is accretion of an estuary area probably due to harbour protection work.

The most spectacular foundation failures were seen in the Granity - Nikau districts.

\section{Contributing factors to damage}

4. (a) This is an area where high quality coal is readily available. Good hot fires are a feature of the district. The result of this is that the brick work of chimneys tends to deteriorate quickly and to lack resistance to lateral forces.

(b) The extensive use of coal also affects corrugated iron roofs. The dilute acid in the air attacks the iron and makes it thin and less resistant to blows from falling bricks. It also complicates the work of repairers.

(c) Many buildings have no continuous ring foundations. In these cases the junction of the building with the piles acts as a hinge in an earthquake and the building is displaced sideways and lands on the ground.

(d) Old brick bearing walls: In the commercial area of Westport there are numerous lime mortar brick bearing wall buildings. Many dating back for 50 years. At least three serious earthquakes have added to the deterioration due to age - such buildings have little structural value.

(e) Nature of the soil: Much of the soil in the area is of an alluvial type. Towards the sea there is sand, some of it accretion built up following harbour works. Numerous watercourses have obviously crossed the area in the past. In many places failure of foundations could be attributed to poor bearing solls.

\section{Comments on aftershocks}

5. The aftershocks continued for some months and reached Richter 5.9 A noticeable feature of the damage was the increment of further damage following each after shock. In some cases where buildings had come through the main shock apparently unscathed, damage was found following several after shocks. A unit masonry hotel was examined each week for five weeks. Each examination revealed fresh damage or the increase of existing damage.

\section{Modern structures}

6. With one noteable exception the few buildings of modem design stood up well. There are several shops designed with portal steel frames and masonry infill panels. These without exception resisted the earthquake with, at the most, minor damage. 